\title{
Soft Tissue Contributions to Pseudopathology of Ribs
}

\author{
Courtney Anson ${ }^{1}$, Bruce Rothschild ${ }^{2,3,4^{*}}$, Virginia Naples ${ }^{5}$ \\ ${ }^{1}$ Anthropology Department, Wooster University, Wooster, USA \\ ${ }^{2}$ Biodiversity Institute, University of Kansas, Lawrence, USA \\ ${ }^{3}$ Anthropology Department, University of Kansas, Lawrence, USA \\ ${ }^{4}$ Department of Medicine, Northeast Ohio Medical University, Rootstown, USA \\ ${ }^{5}$ Department of Biological Sciences, Northern Illinois University, DeKalb, USA \\ Email: "bmr@ku.edu
}

Received February $16^{\text {th }}, 2012$; revised March 22 ${ }^{\text {nd }}, 2012$; accepted April $1^{\text {st }}, 2012$

\begin{abstract}
This study reports the results of a de novo classification and characterization of macroscopically perceivable bone alterations relating to the pathologic significance of rib alterations as noted in defleshed bones. We distinguish between nonspecific two-dimensional color alterations and three-dimensional surface modification which appears to have diagnostic significance. Color alterations were patchy in nature with brown being most prominent, followed by creamy, white and orange, but appear taphonomic in nature. Categorization of three dimensional alterations, e.g., periosteal reaction, bumps and holes, identifies which is specific for diagnosis of tuberculosis. Rib periosteal reaction is significantly more common among individuals with tuberculosis than those with non-tubercular pulmonary disease (Chi square $=$ 33.75, $p<0.0001$ ), cancer (Chi square $=5.82, p<0.02$ ), cardiac disease (Chi square $=7.404, p<0.008$ ), and others (Chi square $=63.19, p<0.0001$ ). This study explains past errors in recognition of the significance of rib alterations.
\end{abstract}

Keywords: Periosteal Reaction; Hypertrophic Osteoarthropathy; Bumps; Color

\section{Introduction}

Ribs have long been a source of scientific, gastronomic and even theological interest (Anon, 1959; Crocker, 1972; Schmidt \& Freyschmidt, 1993; Kunos et al., 1999). Their global anatomic appearance in humans is well characterized (Kunos et al., 1999; Resnick, 2002). Somewhere between the global and histologic appearance (Takahashi \& Frost, 1966; Qui et al., 2003) is a less-well defined area of study (Naples \& Rothschild, 2011). Macroscopic examination is the term applied to study of the character of the external surface of bone (Rothschild \& Martin, 1993, 2006).

Macroscopic examination of ribs reveals details which are helpful in recognizing certain intra-thoracic pathologies (Schmidt \& Freyschmidt, 1993). This information derives predominantly from individuals whose cause of death is recorded and whose skeletons repose in medical collections, such as the Hamman-Todd and Terry Collections (Pfeiffer, 1991; Roberts et al., 1994).

A great challenge to understand the significance of rib alterations is the great variation in the reported frequency of skeletal pathology, even with examination of identical skeletal series (Kelly \& Micozzi, 1984; Pfeiffer, 1991; Roberts et al., 1994; Santos \& Roberts, 2001). The challenge includes distinguishing growth and taphonomic markings (Figure 1) from those related to pathology. Pfeiffer (1991) relates Terry Collection (discussed below) numbers 158, 255, 466, 468 and 522 as exemplary, but our examination fails to identify any abnormalities. It is suspected that she mistook residual (Figure 2) tissue (further cleaned after her examination) for periosteal reaction. Unless her catalogue designations derive from a different system

${ }^{*}$ Corresponding author.

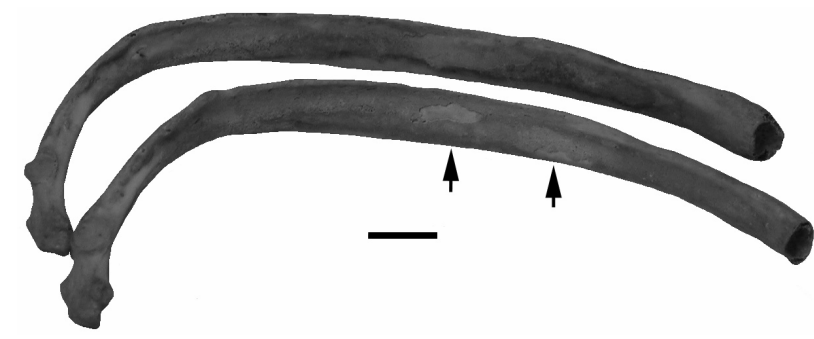

Figure 1.

Inferior view of ribs (Terry Collection 570). Pseudopathology (arrows) related to focal spalling (loss of outer layer of bone). Appearance of residual surrounding bone is sometimes mistaken for periosteal reaction.

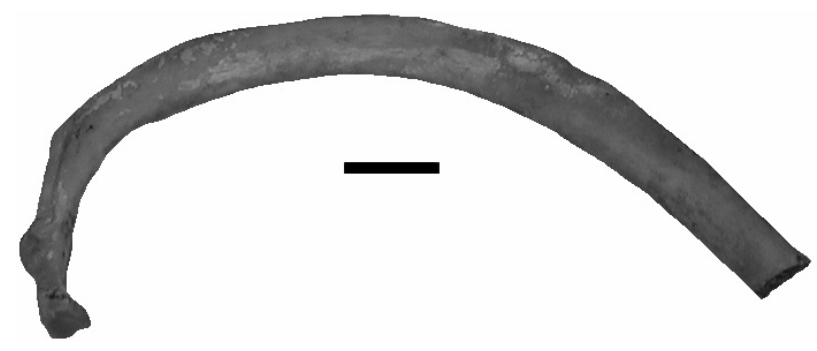

Figure 2.

Inferior view of rib (Terry Collection 424). Residual (adipocere or suponified) tissues show the characteristic white appearance of this form of taphonomic alteration.

than that currently utilized, her report highlights the challenge.

This is analogous to the problem with periosteal reaction af- 
fecting the appendicular skeleton, reported variably as zero or $100 \%$ affliction, again examining the same population (Rose, 1985; Katzenberg, 1992; Byers, 1998; Larson as cited by Powell \& Eisenberg, 1998). Our perception is intermediate and is validated by an independent physical chemical technique predicated upon the second law of thermodynamics (Rothschild \& Rothschild, 2003).

Concern that the same "Emperor's New Clothing Syndrome" might be operative in the lack of reproducibility of findings in rib reports leads to an alternative approach. Are the researchers' variable observations (Rose, 1985; Katzenberg, 1992; Byers, 1998; Larson as cited by Powell \& Eisenberg, 1998) biased by their mentors? Are their diagnostic criteria ever independently validated? Pfeiffer (1991) arbitrarily divides rib lesions into plaque, expansile and resorptive lesions, based on her previous anthropologic experience. It is of interest, however, to identify an independent system.

The current study categorizes macroscopic (as opposed to global) rib alterations and assesses correlation with documented pathology diagnoses.

\section{Materials and Methods}

The sample for this investigation is derived from the wellstudied Terry Collection. The Terry Collection consists of 1709 dissected individuals (of known age, sex, race and usually cause of death) who died in St. Louis, Missouri between 1910 and 1940 and is currently curated at the National Museum of Natural History, Smithsonian Institution (Roberts et al., 1994).

To establish an unbiased approach, an individual (AC) with no prior training in osteology or bone pathology was therefore asked to examine a series of individuals. She was not privy to the perspectives of her coauthors. She was asked to identify any alterations she perceived and to design a system for categorizing them. Two of us (BMR and VN) examined the same skeletal series and found that she successfully identified all ribs with any surface alteration. The system she independently developed for color, texture and cortical character alterations also proved reproducible. Because time did not permit examination of the entire Terry Collection, and biases are often inherent in selection techniques, cohort analysis is pursued. To evaluate rib alterations as life experience(s), it seems appropriate to examine those representing the decades at the turn of the century. Analysis is pursued with the cohort of 443 individuals born in the 20 year period between 1890 and 1909. This sample (Table 1) consists of $52 \%$ males, $77 \%$ of whom were African American.

Tuberculosis is responsible for $26 \%$ of deaths; pneumonia, $10 \%$, cancer, $5 \%$; and heart disease, $15 \%$. Seventy-one of the

Table 1.

Cohorts born between 1890 and 1909.

\begin{tabular}{ccc}
\hline Age & Number & Percent of total \\
\hline $17-19$ & 6 & 1.4 \\
$20-29$ & 89 & 20.1 \\
$30-39$ & 174 & 39.3 \\
$40-49$ & 94 & 21.2 \\
$50-59$ & 50 & 11.3 \\
$>60$ & 30 & 6.8 \\
\hline
\end{tabular}

443 individuals have only acute trauma listed as cause of death, have mortality-unrelated diagnoses (e.g., retroverted uterus) or lack any diagnosis. Unfortunately, associated co-morbid disorders are not provided for those with cause of death listed as traumatic.

Alterations are divided into the following categories: Two dimensional (i.e., color) and three dimensional (e.g., bumps, periosteal reaction and holes). Distribution is recorded according to whether noted alterations affected the proximal (closest to the vertebra), middle or distal (closest to the costal cartilage) portion of the rib.

Venous imprints are recognized on the basis of the classic uniform serpiginous depressions on the rib pleural surface (as opposed to superior or inferior margins). Hypertrophic osteoarthropathy is diagnosed on the basis of specific character of appendicular skeleton periosteal reaction, in the absence of subjacent osteomyelitis or subjacent lytic/blastic metastatic lesions, was common in the time period represented by individuals with tuberculosis in the Terry Collection, as previously described (Rothschild \& Rothschild, 1998).

Diseases in this analysis are divided into the following categories: Pulmonary tuberculosis (labeled tuberculosis), non-tubercular pulmonary disease (labeled pulmonary), cancer (e.g., breast, lung), cardiac and other. The cardiac category encompasses acute and non-acute cardiac events. The latter includes myocarditis, valve disease, endocarditis and heart failure.

Chi square and Fisher Exact tests are performed to assess the significance of correlation of tuberculosis with three-dimensional rib alterations, color variation with rib distribution, symmetry and disease, bumps and holes by diagnosis, location and quantity, periosteal reaction by sex, ethnicity, localization and disease, and venous imprints by disease, symmetry and distribution

\section{Results}

Two dimensional (without macroscopically detectable thickness) and three dimensional phenomena in the other individuals are independently evaluated.

\section{Two Dimensional Observations}

These encompass color changes; divided into chalky, orange, brown, cream, cream-white and white streaks, all of which are patchy in distribution. Additionally, a shiny yellow layer or white thick shiny rib covering is noted on the parietal surface of some ribs (Figure 2), thought related to inadequate preparation (defleshing). Color distribution is delineated by rib in Table 2 and by disease in Table 3. Brown is the most represented patchy discoloration, followed in frequency by creamy, white and orange.

\section{Symmetry}

Color variation is equally distributed as to side, with exception of creamy coloration of the second rib (Chi square $=4.36$, $p<0.04$ ) and brown discolored patches on the fifth (Chi square $=8.20, p<0.004)$. Examined according to disease, variation of symmetry is minimal. The greatest variation is in the $5^{\text {th }}$ ribs among individuals with tuberculosis, but that was not statistically significant (Chi square $=3.67)$. 
Table 2.

Color and vein marking distribution (number affected) according to rib number and affected side (L-R).

\begin{tabular}{|c|c|c|c|c|c|c|c|c|c|c|c|c|}
\hline Color/Rib & $1^{\text {st }}$ & $2^{\text {nd }}$ & $3^{\text {rd }}$ & $4^{\text {th }}$ & $5^{\text {th }}$ & $6^{\text {th }}$ & $7^{\text {th }}$ & $8^{\text {th }}$ & $9^{\text {th }}$ & $10^{\text {th }}$ & $11^{\text {th }}$ & $12^{\text {th }}$ \\
\hline Creamy & $3-3$ & $14-5$ & $15-16$ & $12-14$ & $12-14$ & $10-13$ & $14-15$ & $19-20$ & $26-20$ & $15-18$ & $19-18$ & $6-6$ \\
\hline White & $2-3$ & $5-7$ & $7-5$ & $8-5$ & $8-7$ & $6-6$ & $12-9$ & $10-12$ & $10-17$ & $7-13$ & $11-16$ & $5-7$ \\
\hline Brown & $3-7$ & $17-17$ & $28-21$ & $34-27$ & $35-20$ & $28-32$ & $25-27$ & $32-22$ & $33-33$ & $32-32$ & $24-25$ & $5-5$ \\
\hline Orange & $4-0$ & $6-1$ & $5-1$ & $8-4$ & $7-2$ & $6-5$ & $4-5$ & $7-6$ & $10-7$ & $7-2$ & $8-2$ & $3-0$ \\
\hline Vein Marking & $0-0$ & $6-8$ & $15-14$ & $16-14$ & $15-15$ & $17-16$ & $1-14$ & $8-13$ & $7-13$ & $9-12$ & $7-10$ & $4-6$ \\
\hline
\end{tabular}

Table 3.

Number of rib discolorations according to rib number, affected side (L-R) and diagnosis.

\begin{tabular}{|c|c|c|c|c|c|c|c|c|c|c|c|c|}
\hline Rib/Disease (\#) & $1^{\mathrm{st}}$ & $2^{\text {nd }}$ & $3^{\text {rd }}$ & $4^{\text {th }}$ & $5^{\text {th }}$ & $6^{\text {th }}$ & $7^{\text {th }}$ & $8^{\text {th }}$ & $9^{\text {th }}$ & $10^{\text {th }}$ & $11^{\text {th }}$ & $12^{\text {th }}$ \\
\hline $\mathrm{TB}^{*}(117)$ & $\begin{array}{c}6-1 \\
3 \%\end{array}$ & $\begin{array}{c}30-11 \\
18 \%\end{array}$ & $\begin{array}{c}30-23 \\
22 \%\end{array}$ & $\begin{array}{c}31-23 \\
22 \%\end{array}$ & $\begin{array}{c}31-19 \\
22 \%\end{array}$ & $\begin{array}{c}23-28 \\
22 \%\end{array}$ & $\begin{array}{c}23-28 \\
22 \%\end{array}$ & $\begin{array}{c}26-27 \\
22 \%\end{array}$ & $\begin{array}{c}27-30 \\
24 \%\end{array}$ & $\begin{array}{c}26-26 \\
22 \%\end{array}$ & $\begin{array}{c}28-23 \\
22 \%\end{array}$ & $\begin{array}{c}5-3 \\
3 \%\end{array}$ \\
\hline Pulm (46) & $\begin{array}{c}3-2 \\
7 \%\end{array}$ & $\begin{array}{l}5-8 \\
15 \%\end{array}$ & $\begin{array}{l}6-5 \\
13 \%\end{array}$ & $\begin{array}{l}6-5 \\
13 \%\end{array}$ & $\begin{array}{c}7-11 \\
20 \%\end{array}$ & $\begin{array}{l}6-7 \\
13 \%\end{array}$ & $\begin{array}{l}5-5 \\
11 \%\end{array}$ & $\begin{array}{c}11-7 \\
20 \%\end{array}$ & $\begin{array}{c}10-11 \\
22 \%\end{array}$ & $\begin{array}{l}6-8 \\
15 \%\end{array}$ & $\begin{array}{c}7-14 \\
22 \%\end{array}$ & $\begin{array}{c}5-3 \\
9 \%\end{array}$ \\
\hline Cancer (20) & $\begin{array}{c}0-0 \\
0 \%\end{array}$ & $\begin{array}{l}0-1 \\
5 \%\end{array}$ & $\begin{array}{c}2-0 \\
5 \%\end{array}$ & $\begin{array}{c}1-0 \\
5 \%\end{array}$ & $\begin{array}{c}2-0 \\
5 \%\end{array}$ & $\begin{array}{c}3-0 \\
8 \%\end{array}$ & $\begin{array}{c}1-1 \\
5 \%\end{array}$ & $\begin{array}{l}4-2 \\
15 \%\end{array}$ & $\begin{array}{l}6-1 \\
20 \%\end{array}$ & $\begin{array}{c}1-1 \\
5 \%\end{array}$ & $\begin{array}{l}1-3 \\
10 \%\end{array}$ & $\begin{array}{c}0-1 \\
5 \%\end{array}$ \\
\hline Heart (68) & $\begin{array}{c}3-4 \\
6 \%\end{array}$ & $\begin{array}{c}4-3 \\
6 \%\end{array}$ & $\begin{array}{c}10-8 \\
13 \%\end{array}$ & $\begin{array}{c}12-11 \\
18 \%\end{array}$ & $\begin{array}{c}12-3 \\
12 \%\end{array}$ & $\begin{array}{c}10-10 \\
15 \%\end{array}$ & $\begin{array}{c}12-11 \\
16 \%\end{array}$ & $\begin{array}{c}18-16 \\
25 \%\end{array}$ & $\begin{array}{c}22-21 \\
32 \%\end{array}$ & $\begin{array}{c}17-22^{\S} \\
29 \%\end{array}$ & $\begin{array}{c}17-19^{\S} \\
26 \%\end{array}$ & $\begin{array}{l}6-8 \\
10 \%\end{array}$ \\
\hline Other (189) & $\begin{array}{c}0-3 \\
1 \%\end{array}$ & $\begin{array}{l}7-5 \\
3 \%\end{array}$ & $\begin{array}{l}6-7 \\
4 \%\end{array}$ & $\begin{array}{c}12-7 \\
5 \%\end{array}$ & $\begin{array}{c}11-9 \\
5 \%\end{array}$ & $\begin{array}{c}11-12 \\
6 \%\end{array}$ & $\begin{array}{c}11-10 \\
6 \%\end{array}$ & $\begin{array}{c}12-7 \\
5 \%\end{array}$ & $\begin{array}{c}13-13 \\
7 \%\end{array}$ & $\begin{array}{c}13-11 \\
6 \%\end{array}$ & $\begin{array}{c}6-4 \\
3 \%\end{array}$ & $\begin{array}{c}3-2 \\
2 \%\end{array}$ \\
\hline
\end{tabular}

${ }^{*} \mathrm{~TB}=$ Tuberculosis; Pulm = Pulmonary. ${ }^{\S}$ Three tenth and two eleventh ribs were creamy white on left and the only such ones.

\section{Disease}

Presence of patchy color is more common in the second rib among individuals with tubercular and non-pulmonary disease, than in the other categories (Chi square $=45.22, p<0.0001$ ). Patchy color changes are more common in the third, fourth, sixth and seventh ribs of individuals with tuberculosis than with non-tubercular pulmonary disease (Chi square $=4.79, p<0.04$ ). Limiting comparison to the $4^{\text {th }}$ rib, involvement among individuals is statistically more common than with cardiac disease (Chi square $=18.005, p<0.0005$ ). Seventh rib comparison (of cardiac with tuberculosis groups) reveals Chi square of 15.333 , $p<0.0006$; sixth, 17.66, $p<0.00006$; and third, 16.241, $p<$ 0.0006 . Distribution in cancer shows predilection for the eighth and ninth ribs (Chi square $=14.54, p<0.0007$ ). Cardiac disease has predilection for the eighth through eleventh ribs (Chi square $=68.685, p<0.0001$ ).

\section{Three Dimensional Observations}

Three dimensional changes are divided into periosteal reaction (Figure 3), bumps and holes, as opposed to enthesial reaction (Figure 4). The latter represent calcification/ossification of the aponeuroses of intercostal muscles. Three dimensional markings are present in 231 (52\% of the sample studied (Table 4). Individuals without tuberculosis are significantly less likely to have any three-dimensional changes (Chi square $=73.86, p<$ 0.0001). Bumps and holes are equally present in all groups (Chi square $=0.15$, non-significant). One individual with cancer has air bubble-like bumps on his ribs.

\section{Holes}

The seventeen observed holes (Table 4) were equally dis-

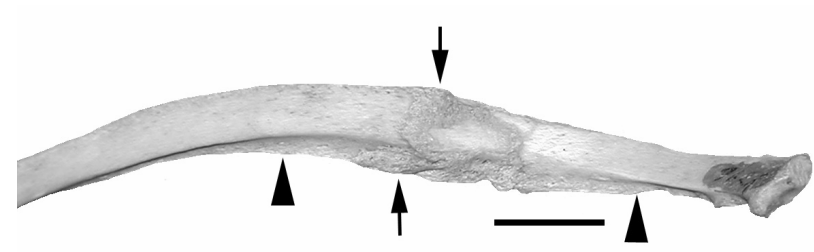

Figure 3.

Proximal internal view of rib (Terry Collection 962). Focal periosteal reaction (arrow) partially overlying area of enthesial calcification (arrowheads).

Table 4.

Number of individuals with three-dimensional markings according to diagnosis.

\begin{tabular}{ccccccc}
\hline $\begin{array}{c}\text { Markings/ } \\
\text { Diagnosis }\end{array}$ & None & $\begin{array}{c}\text { Number } \\
\text { Affected }\end{array}$ & Bumps & Holes & $\begin{array}{c}\text { Periosteal } \\
\text { Reaction }\end{array}$ & $\begin{array}{c}\text { Number } \\
\text { Evaluated }\end{array}$ \\
\hline Tuberculosis & 22 & 95 & 23 & 3 & 69 & 117 \\
& $19 \%$ & $81 \%$ & $20 \%$ & $3 \%$ & $59 \%$ & \\
Pulmonary & 35 & 11 & 7 & 2 & 4 & 46 \\
& $76 \%$ & $24 \%$ & $15 \%$ & $4 \%$ & $9 \%$ & \\
Cancer & 12 & 8 & $3^{*}$ & 4 & 5 & 20 \\
& $60 \%$ & $40 \%$ & $15 \%$ & $6 \%$ & $25 \%$ & \\
Cardiac & 35 & 33 & 11 & 4 & 18 & 68 \\
& $51 \%$ & $49 \%$ & $16 \%$ & $6 \%$ & $26 \%$ & \\
Other & 127 & 72 & 30 & 3 & 29 & 189 \\
\hline
\end{tabular}

${ }^{*}$ One with bubbles. 


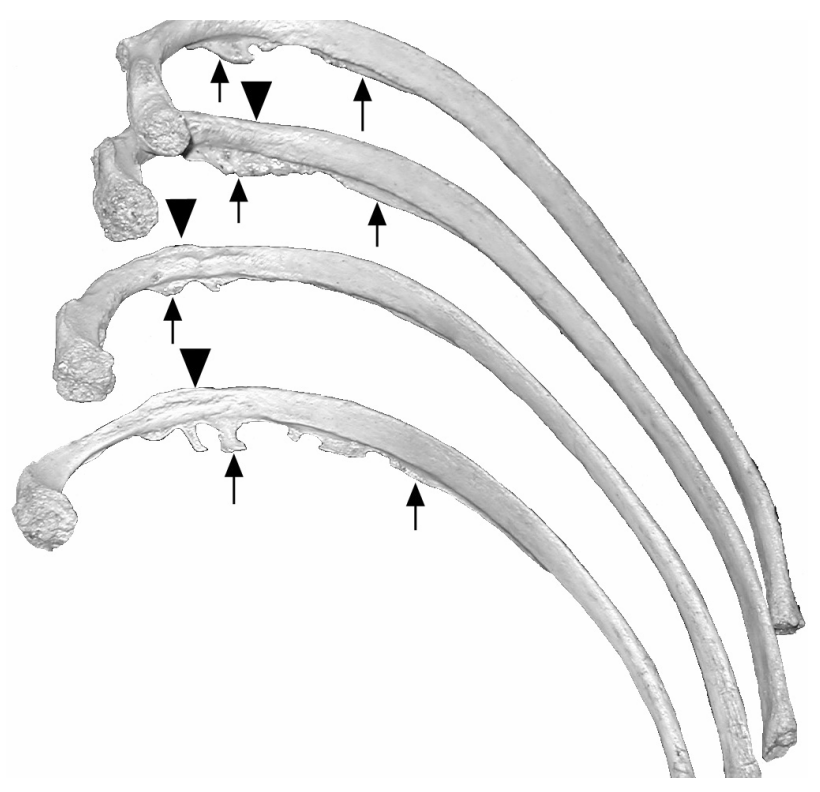

Figure 4.

Internal view of ribs (Terry Collection 1577). Calcification/ossification (enthesial reaction) of the aponeuroses of intercostal muscles (arrows). Note irregular articular surface of rib portion of costovertebral joints, related to the underlying spondyloarthropathy. Wrinkled appearance (arrowheads) is an artifact of preservation.

tributed across disease processes. Numbers were too small for statistical analysis of correlations, so they were not further analyzed.

\section{Bumps}

The distribution of bumps by rib segment is illustrated in
Table 5 (as symmetrical). The pulmonary group has an average of 16.1 segments (divided into left and right proximal, middle and distal) with bumps per individual, contrasted with 2.3 for tuberculosis (Chi square $=221.946, p<0.00001$ ), 1.3 for cancer, and 1.0 for both cardiac and other. Tuberculosis significantly affects more rib sections (Chi square $=19.944, p<$ 0.0005 ) than the cancer, cardiac or other categories.

Bumps predominantly affect the posterior segments of all ribs in the tuberculosis and pulmonary groups, except for the seventh (Chi square $=29.24, p<0.0001$ ). Anterior segments are predominantly involved in the seventh. This contributes to seventh ribs having maximal involvement in all disease groups, although the pulmonary group maintains this frequency across the $4^{\text {th }}$ to $7^{\text {th }}$ ribs, with only slight reduction in the $2^{\text {nd }}, 3^{\text {rd }}, 9^{\text {th }}$, $9^{\text {th }}$ and $10^{\text {th }}$. Ninth and $10^{\text {th }}$ rib bumps are more common among individuals with non-tubercular pulmonary disease (Chi square $=102.822, p<0.00001$ ).

One individual in this series has bubble-like bumps (Table 4) on ribs. While cyst-like changes are reported as caused by osteonecrosis in polyarteritis nodosum (Schmidt \& Freyschmidt, 1993), bubbles seem a unique observation. Their etiology in this individual with cancer is unclear.

\section{Periosteal Reaction}

Periosteal reaction is present in 117 individuals (26.4\%), with frequency independent of sex and race for all diseases, including tuberculosis (Chi square $=3.522$ and 1.071, respectively, non-significant). Right and left sides are equally affected in the non-pulmonary categories. Rib periosteal reaction in tuberculosis and non-tubercular pulmonary disease affects the right side $20 \%$ more often than the left. Exception is the left $12^{\text {th }}$ rib, affected in 4 individuals with tuberculosis (contrasted with the right, in only one), but the difference is not statistically

Table 5.

Rib bumps as a function of rib number, region of rib, ${ }^{*}$ side affected and diagnosis.

\begin{tabular}{|c|c|c|c|c|c|c|c|c|c|c|c|c|c|}
\hline Rib/Diagnosis & Side & $1^{\text {st }}$ & $2^{\text {nd }}$ & $3^{\text {rd }}$ & $4^{\text {th }}$ & $5^{\text {th }}$ & $6^{\text {th }}$ & $7^{\text {th }}$ & $8^{\text {th }}$ & $9^{\text {th }}$ & $10^{\text {th }}$ & $11^{\text {th }}$ & $12^{\text {th }}$ \\
\hline \multirow[t]{2}{*}{ Tuberculosis } & Right & & & 1 Post & $1 \mathrm{~A}-\mathrm{P}$ & $\begin{array}{l}1 \text { M-P } \\
1 \text { Post }\end{array}$ & $1 \mathrm{M}-\mathrm{P}$ & $\begin{array}{l}9 \text { Ant } \\
1 \text { A-M } \\
1-\text { All }\end{array}$ & 1 Mid & 1 Post & & & \\
\hline & Left & & 1 Post & 1 Post & 1 All & $\begin{array}{l}1 \text { All } \\
1 \text { Post }\end{array}$ & $\begin{array}{c}1 \mathrm{All} \\
1 \mathrm{M}-\mathrm{P}\end{array}$ & 1 All & & & & $\begin{array}{c}1 \mathrm{All} \\
1 \mathrm{M}-\mathrm{P}\end{array}$ & $\begin{array}{l}1 \text { All } \\
1 \text { Post }\end{array}$ \\
\hline \multirow[t]{2}{*}{ Pulmonary } & Right & $1 \mathrm{~A}-\mathrm{M}$ & $\begin{array}{l}1 \text { All } \\
1 \text { Post }\end{array}$ & $\begin{array}{c}1 \text { All } \\
1 \text { Post }\end{array}$ & $\begin{array}{c}1 \text { All } \\
1 \mathrm{M}-\mathrm{P}\end{array}$ & $\begin{array}{c}1 \text { All } \\
1 \mathrm{M}-\mathrm{P}\end{array}$ & $\begin{array}{l}1 \text { All } \\
3 \text { Post }\end{array}$ & $\begin{array}{l}1 \text { All } \\
1 \text { Ant } \\
1 \text { A-P }\end{array}$ & $\begin{array}{c}1 \text { All } \\
2 \text { Post }\end{array}$ & $\begin{array}{l}1 \text { All } \\
1 \text { Post }\end{array}$ & $\begin{array}{l}1 \text { All } \\
1 \text { Post }\end{array}$ & $\begin{array}{c}1 \text { All } \\
1 \text { Post }\end{array}$ & \\
\hline & Left & $2 \mathrm{~m}-\mathrm{P}$ & $\begin{array}{c}1 \mathrm{All} \\
1 \mathrm{M}-\mathrm{P}\end{array}$ & $\begin{array}{c}1 \text { All } \\
1 \mathrm{M}-\mathrm{P}\end{array}$ & $\begin{array}{l}1 \text { All } \\
1 \mathrm{M}-\mathrm{P} \\
1 \mathrm{Mid}\end{array}$ & $\begin{array}{c}2 \text { All } \\
1 \mathrm{M}-\mathrm{P}\end{array}$ & $\begin{array}{c}1 \mathrm{All} \\
1 \mathrm{M}-\mathrm{P}\end{array}$ & $\begin{array}{c}1 \text { All } \\
2 \text { M-P }\end{array}$ & $\begin{array}{l}1 \text { All } \\
1 \text { M-P } \\
1 \text { Post }\end{array}$ & $\begin{array}{c}1 \text { All } \\
1 \mathrm{M}-\mathrm{P} \\
1 \mathrm{Ant}\end{array}$ & $\begin{array}{c}1 \text { All } \\
1 \mathrm{M}-\mathrm{P}\end{array}$ & & $\begin{array}{l}1 \text { All } \\
1 \mathrm{M}-\mathrm{P} \\
1 \mathrm{Mid}\end{array}$ \\
\hline \multirow[t]{2}{*}{ Cancer } & Right & & & & & $1 \mathrm{M}-\mathrm{P}$ & & $1 \mathrm{~A}-\mathrm{M}$ & & & & & \\
\hline & Left & & & & & & & & & & & & \\
\hline \multirow[t]{2}{*}{ Heart } & Right & 1 Post & & & & & & 7 Ant & & & $1 \mathrm{~A}-\mathrm{M}$ & & \\
\hline & Left & 1 Ant & & & & & & 1 Post & & & & & \\
\hline \multirow[t]{2}{*}{ Other } & Right & 2 Post & $1 \mathrm{Mid}$ & $1 \mathrm{Mid}$ & $1 \mathrm{Mid}$ & $1 \mathrm{~A}-\mathrm{M}$ & $1 \mathrm{Mid}$ & $\begin{array}{l}3 \text { Ant } \\
1 \text { A-M }\end{array}$ & 1 Mid & $1 \mathrm{M}-\mathrm{P}$ & $\begin{array}{l}1 \text { All } \\
1 \text { Mid }\end{array}$ & 1 Mid & $1 \mathrm{Mid}$ \\
\hline & Left & 2 post & $1 \mathrm{M}-\mathrm{P}$ & & & & $\begin{array}{l}1 \text { Mid } \\
1 \text { A-M }\end{array}$ & & & & & & \\
\hline
\end{tabular}

${ }^{*}$ Ant = Anterior; Mid = Middle; Post = Posterior; A-P = anterior and posterior; A-M = anterior and middle; M-P = middle and posterior; All = Anterior, posterior and middle affected. 
significant (Chi square $=0.01$ ). As involvement shows no side favoritism, distribution of only the right side is illustrated in Table 6. A flat, bell-shaped curve describes the distribution for all groups.

Rib periosteal reaction is significantly more common among individuals with tuberculosis than those with non-tubercular pulmonary disease (Chi square $=33.75, p<0.0001$ ), cancer (Chi square $=5.82, p<0.02$ ), cardiac disease (Chi square $=$ $7.404, p<0.008$ ), and others (Chi square $=63.19, p<0.0001$ ). As the proximal third of ribs is involved in 50\% (typically associated with involvement of middle or distal third), that portion was chosen to illustrate relative frequency and extent of rib involvement in the various disorders studied (Table 6).

\section{Venous Imprints}

Among three sites on each of 24 ribs, 149 examples (0.35\%) of venous imprints (of 4284 possible segments) are found among individuals with tuberculosis, two $(0.12 \%)$ with pneumonia, eight $(1.0 \%)$ with cancer, $8(0.33 \%)$ with cardiac disease; and $62(0.94 \%)$ with other. Venous imprints are more common among individuals in the cancer and other categories than in those with tuberculosis, pulmonary disease or cardiac disease (Chi square $=30.371, p<0.0001$ ).

Distribution of venous imprints on ribs is equal left and right (Table 2), with the exception of the $7^{\text {th }}$ rib, which manifests significant side (left predominant) bias (Chi square $=11.3, p<$ 0.001). Rib seven is also unique in that the frequency of affliction with tuberculosis is statistically greater than with all other groups combined (Chi square $=8.43, p<0.005$ ). However, the frequency in tuberculosis and the group designated as other can not be distinguished (Chi square $=2.72$, non-significant).

\section{Hypertrophic Osteoarthropathy}

Only one individual each with cancer, pneumonia and tuberculosis have hypertrophic osteoarthropathy in this series. Among those "other" individuals with periosteal reaction, 35 have syphilis; 22, renal disease; 7, cirrhosis; 14, infections; and 2 are drug addicts.

\section{Discussion}

Quid significat' might be said about the status of ribs. Consistent with very brief, though important, mention in the theologic literature and eclectic discussion in culinary literature is anatomic literature coverage of the topic. While number of ribs, general shape and gross variation have been discussed (Schmidt \& Freyschmidt, 1993; Glass et al., 2002; Resnick, 2002), the significance of macroscopic variation is only minimally ex-

Table 6.

Distribution (number affected) of periosteal reaction as a function of right rib number and disease.

\begin{tabular}{ccccccccccccc}
\hline Rib/Diagnosis & $1^{\text {st }}$ & $2^{\text {nd }}$ & $3^{\text {rd }}$ & $4^{\text {th }}$ & $5^{\text {th }}$ & $6^{\text {th }}$ & $7^{\text {th }}$ & $8^{\text {th }}$ & $9^{\text {th }}$ & $10^{\text {th }}$ & $11^{\text {th }}$ & $12^{\text {th }}$ \\
\hline Tuberculosis & 3 & 15 & 26 & 28 & 23 & 23 & 19 & 20 & 20 & 13 & 10 & 1 \\
Pulmonary & 0 & 1 & 2 & 1 & 0 & 3 & 3 & 2 & 2 & 1 & 1 \\
Cancer & 1 & 1 & 1 & 0 & 1 & 0 & 1 & 1 & 1 & 0 & 0 \\
Heart & 3 & 5 & 6 & 7 & 6 & 7 & 8 & 6 & 7 & 5 & 1 \\
Other & 5 & 6 & 6 & 5 & 8 & 8 & 6 & 6 & 4 & 3 & 2 \\
\hline
\end{tabular}

plored. What is anomaly and what is pathology?

The current study tries to identify hypotheses for the various types of macroscopic rib alterations. It does not address wellcharacterized gross (global) pathologies. What is the significance of the changes present in ribs? They seem divided into three basic phenomena: Alteration in the outermost layer of bone (periosteal reaction), focal enlargements (bumps) and defects (holes).

Bumps are equally present in all groups, suggesting that they are anomalies, not disease. They have no differential significance for distinguishing among the diseases studied and may well represent normal variation. Thus they should at least not be further considered in differential diagnosis. Holes are infrequent and must be evaluated on their own (e.g., diffuse damage from multiple myeloma; Figure 5), without epidemiologic consideration. Specific explanation for holes is beyond the scope of the present study of ribs and, indeed, has not been defined for other areas of the skeleton (Rothschild \& Woods, 1993). They do not appear to be related to over-maceration.

Periosteal reaction appears to be a useful diagnostic finding in ribs. Its independence of age, race and side involved greatly simplifies skeletal analysis, especially when ribs are only fragmentary in their preservation. Relationship of rib lesions to tuberculosis is suggested by Kelly and El-Najjar in 1980, while Molto (1990) discusses their differential diagnosis, including osteomyelitis and histiocytosis. Blastic and lytic rib lesions may represent actual infection or tumor. Laminated periosteal reaction is reported in leukemia and sclerotic areas, in mastocytosis (Schmidt \& Freyschmidt, 1993). Rib periosteal reaction is independent of periosteal reaction affecting the peripheral skeleton and of hypertrophic osteoarthropathy. Pfeiffer (1991) reports calcific plaques as a periosteal reaction. However in our survey of rib surface morphology the plaques identified are associated either with the inner surface of the intercostal musculature or the parietal pleura (Naples \& Rothschild, 2011). These plaques were easily removed from the soft tissue surfaces to which they had been adhered and were clearly associated with dried soft tissues remaining on imperfectly cleaned ribs. They do not actually represent periosteal reaction. Cyst-

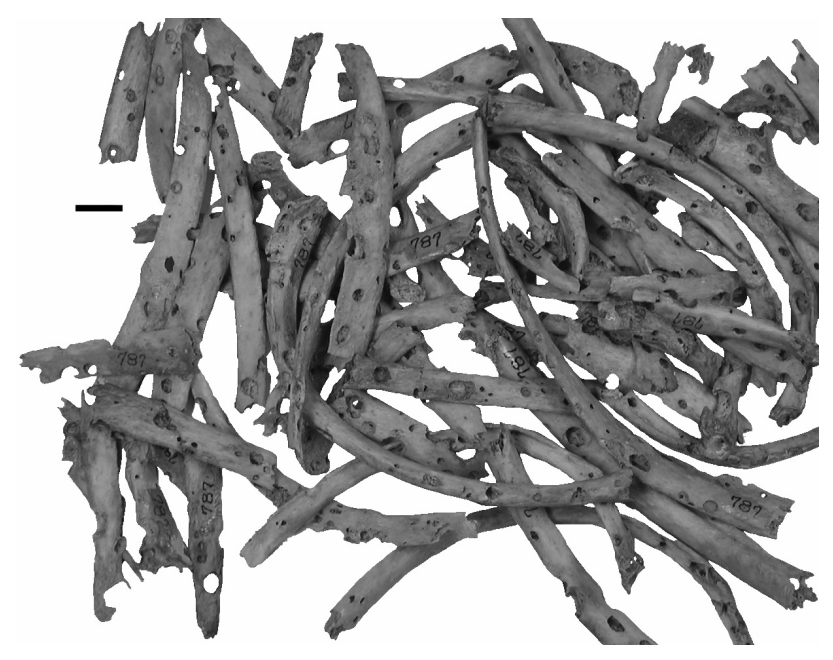

Figure 5.

Macroscopic view of rib fragments (Terry Collection 787). Diffuse circular (actually spheroid) holes caused by multiple myelona. Note taphonomic alterations occasionally altered the circular appearance. 
like changes are reported in osteonecrosis related to polyarteritis nodosum (Schmidt \& Freyschmidt, 1993). Subperiosteal rib resorption (not noted in this study) is found in hyperparathyroidism (Glass et al., 2002).

What are the implications of rib lesions for diagnosis of tuberculosis?

Periosteal reaction is significantly more common in tuberculosis than with other pulmonary diseases and more frequent than in cardiac disease and cancer. Rib periosteal reaction is independent (statistically) of peripheral periosteal reaction and hypertrophic osteoarthropathy. Osseous involvement in tuberculosis is reported in humans at a frequency of 5\% (Nathanson \& Cohen, 1941; Rosencrantz et al., 1941; LaFond, 1958; Sen, 1961; Davies et al., 1984). Roberts et al. (1994: p. 172) report "chronic inflammatory change of the visceral surfaces of one or more ribs" in $24.2 \%$ of individuals examined. She states that $52.1 \%$ have pulmonary disease and $61.6 \%$ have tuberculosis. $22.2 \%$ of those who died of non-tubercular pulmonary disease have rib lesions. More than half the rib lesions in her study are in individuals with non-pulmonary causes of death. If her study is valid, observation of rib lesions would not be a useful diagnostic tool. These numbers contrast with those of Kelly and Micozzi (1984), who reported rib periosteal reaction or lytic lesions (holes) in $8.98 \%$ of individuals whose cause of death is recorded as tuberculosis. Equal distribution of color variation among the ribs most in contact with the pleura suggests that adherent (not fully removed in the preparation process) material, rather the rib itself, may be the source of confusion in the study by Roberts et al. (1994).

However, it is more likely that the great variation in the reported frequency of skeletal pathology other than ribs (Kelly \& Micozzi, 1984; Pfeiffer, 1991; Roberts et al., 1994; Santos \& Roberts, 2001) represents a lack of standardization and validation of identification skills. The high frequency of alleged rib periosteal reaction among individuals without tuberculosis in the study by Roberts et al. (1994) is significantly deviant from what was observed in the present study and unexplained, except that perhaps all rib alterations were lumped and normal muscle scars (Naples \& Rothschild, 2011) (e.g., enhanced by the enhanced respiratory muscle activity in pulmonary disease) are confused with the periostitis that seems more disease specific. Rib periosteal reaction in isolated skeletons is not diagnostic. However, population analysis may be more informative, especially if the first rib is available for assessment. Periostitis of the first rib is parsimonious with the relative specificity of apical pulmonary involvement for tuberculosis (Rothschild \& Martin, 2006).

Osseous involvement in tuberculosis has been reported in humans at a frequency of 5\% (Nathanson \& Cohen, 1941; Rosencrantz et al., 1941; LaFond, 1958; Sen, 1961; Davies et al., 1984). Observations in the current study suggest that is important epidemiologic information, but does not appear to consider rib involvement. As rib preservation in archeologic sites is highly variable, one might think that periosteal reaction could be easily overlooked. However, the relatively equivalent occurrence in the third through ninth ribs suggest it is feasible. Equal involvement (by periosteal reaction) of the third through ninth ribs is suggested as an additional marker for recognition of tuberculosis.

\section{REFERENCES}

Anonymous (1959). The holy scriptures. According to Masoretic text.
Philadelphia: Jewish Publication Society of America.

Byers, S. N. (1998). The skeletal biology of the lower Mississippi River valley. American Journal of Physical Anthropology, 26, 116.

Crocker, B. (1972). Betty Crocker's cookbook. New York: Golden Press.

Davies, P. D., Humphries, M. J., Byfield, S. P., Nunn, A. J., Darbyshire, J. H., Cirtron, K. M., \& Fox, W. (1984). Bone and joint tuberculosis. Journal of Bone and Joint Surgery, 66B, 326-330.

Glass, R. B., Norton, K. I., Mitre, S. A., \& Kang, E. (2002). Pediatric ribs: A spectrum of abnormalities. RadioGraphics, 22, 87-104.

Katzenberg, M. A. (1992). Changing diet and health in pre- and protohistoric Ontario. University of Pennsylvania MASCA Research $\mathrm{Pa}$ pers in Science and Archeology, 9, 23-31.

Kelly, M. A., \& El-Najjar, M. (1980). Natural variation and differential diagnosis of skeletal lesions. American Journal of Physical Anthropology, 52, 153-167. doi:10.1002/ajpa.1330520202

Kelley, M. A., \& Micozzi, M. S. (1984). Rib lesions and chronic pulmonary tuberculosis. American Journal of Physical Anthropology, 65, 381-386. doi:10.1002/ajpa.1330650407

Kunos, C. A., Simpson, S. W., Russell, K. F., \& Hershkovitz, I. (1999). First rib metamorphosis: Its possible utility for human age-at-death estimation. American Journal of Physical Anthropology, 110, 303323.

doi:10.1002/(SICI)1096-8644(199911)110:3<303::AID-AJPA4>3.0. $\mathrm{CO} ; 2-\mathrm{O}$

LaFond, E. M. (1958). An analysis of adult skeletal tuberculosis. Journal of Bone and Joint Surgery, 40, 346-364.

Molto, J. E. (1990). Differential diagnosis of rib lesions: A case study from Middle Woodland Sourthern Ontario circa 20 A.D. American Journal of Physical Anthropology, 83, 439-447. doi:10.1002/ajpa.1330830405

Nathanson, L., \& Cohen, W. (1941). A statistical and roentgen analysis of two hundred cases of bone and joint tuberculosis. Radiology, 36, 550-567.

Pfeiffer, S. (1991). Rib lesions and new world tuberculosis. International Journal of Osteoarchaeology, 1, 191-198. doi:10.1002/oa.1390010309

Pineda, C., Coindreau, J., Vazquez, J., Nava, A. \& Martinez-Lavin, M. (1999). The significance of rib notching in Takayasu arteritis. Arthritis \& Rheumatism, 42, S211.

Powell, M. L., \& Eisenberg, L. E. (1998). Syphilis in Mound Builders’ bones: Treponematosis in the prehistoric southwest. American Journal of Physical Anthropology, 26, 180.

Qiu, S., Fyhrie, D. P., Palnitkar, S., \& Rao, D. S. (2003). Histomorphiometric assessment of Haversian canal and osteocyte lacunae in different-sized osteons in human rib. Anatomical Record, 272A, 520525. doi:10.1002/ar.a.10058

Resnick, D. (2002). Diagnosis of bone and joint disorders. Philadelphia: Saunders.

Roberts, C., Lucy, D. \& Manchester, K. (1994). Inflammatory lesions of ribs: An analysis of the terry collection. American Journal of Physical Anthropology, 95, 169-182. doi:10.1002/ajpa.1330950205

Rose, J. C. (1985). Gone to a better land. Arkansas Archeological Survey Research Service, 25, 1-216.

Rosencrantz, E. A., Priscitelli, A., \& Bost, F. C. (1941). An analytical study of bone and joint lesions in relation to chronic pulmonary tuberculosis. Journal of Bone and Joint Surgery, 23, 630-638.

Rothschild, B. M., \& Martin, L. D. (1993). Paleopathology: Disease in the fossil record. London: CRC Press.

Rothschild, B. M., \& Martin, L. D. (2006). Skeletal impact of disease. Albuquerque: New Mexico Museum of Natural History Press.

Naples, V. L., \& Rothschild, B. M. (2011). Do ribs actually have a bare area? A new analysis. Journal of Comparative Human Biology, 62, 368-373. doi:10.1016/j.jchb.2011.08.001

Rothschild, B. M., \& Rothschild, C. (1998). Recognition of hypertrophic osteoarthropathy in skeletal remains. Journal of Rheumatology, 25, 2221-2227.

Rothschild, B. M., \& Rothschild, C. (2003). Thermodynamic resolution of periosteal reaction and taphonomic change. Reumatismo, 55, 195201.

Rothschild, B. M., \& Woods, R. J. (1993). Implications of isolated osseous erosions related to population skeletal health. Historical Bi- 


\section{ANSON ET AL.}

ology, 7, 21-28. doi:10.1080/10292389309380441

Santos, A. L., \& Roberts, C. A. (2001). A picture of tuberculosis in young Portuguese people in the Early $20^{\text {th }}$ century: A multidisciplinary study of the skeletal and historical evidence. American Journal of Physical Anthropology, 115, 38-50. doi:10.1002/ajpa.1054

Schmidt, H., \& Freyschmidt, J. (1993). Kohler/Zimmer borderlands of normal and early pathological findings in skeletal radiology (4th ed.).
New York: Thieme.

Sen, D. K. (1961). Skeletal tuberculosis associated with pulmonary tuberculosis. Journal of the Indian Medical Association, 36, 146-149.

Takahashi, H., \& Frost, H. M. (1966). Age and sex related changes in the amount of cortex of normal human ribs. Acta Orthopaedica Scandinavica, 37, 122-130. doi:10.3109/17453676608993272 